Article

\title{
Application of Geoinformation Systems for Assessment of Effective Integration of Renewable Energy Technologies in the Energy Sector of Ukraine
}

\author{
Olga Ostapenko ${ }^{1} \mathbb{D}$, Piotr Olczak ${ }^{2} \mathbb{D}$, Viktor Koval ${ }^{3, *}$, Larysa Hren ${ }^{4}$, Dominika Matuszewska ${ }^{5}$ \\ and Olena Postupna 6
}

check for updates

Citation: Ostapenko, O.; Olczak, P.; Koval, V.; Hren, L.; Matuszewska, D.; Postupna, O. Application of Geoinformation Systems for Assessment of Effective Integration of Renewable Energy Technologies in the Energy Sector of Ukraine. Appl. Sci. 2022, 12, 592. https://doi.org/ 10.3390/app12020592

Academic Editor: Yannis Maniatis

Received: 3 December 2021

Accepted: 4 January 2022

Published: 7 January 2022

Publisher's Note: MDPI stays neutral with regard to jurisdictional claims in published maps and institutional affiliations.

Copyright: (c) 2022 by the authors. Licensee MDPI, Basel, Switzerland. This article is an open access article distributed under the terms and conditions of the Creative Commons Attribution (CC BY) license (https:// creativecommons.org/licenses/by/ $4.0 /)$.
1 Department of Heat Power Engineering, Vinnytsia National Technical University, 21021 Vinnytsia, Ukraine; ostapenko@vntu.edu.ua

2 Mineral and Energy Economy Research Institute, Polish Academy of Sciences, 31-261 Krakow, Poland; olczak@min-pan.krakow.pl

3 National Academy of Sciences of Ukraine, 01030 Kyiv, Ukraine

4 Kharkiv Polytechnic Institute, National Technical University, 61002 Kharkiv, Ukraine; Larysa.Hren@khpi.edu.ua

5 Department of Thermal and Fluid Flow Machines, Faculty of Energy and Fuels, AGH University of Science and Technology, 30 Mickiewicza Ave., 30-059 Krakow, Poland; dommat@agh.edu.pl

6 Training Research and Production Center, National University of Civil Defence of Ukraine, 61023 Kharkiv, Ukraine; nuczu@dsns.gov.ua

* Correspondence: koval@otei.odessa.ua or victor-koval@ukr.net

\begin{abstract}
The scientific novelty of the results presented in this article is to substantiate and expand the possibilities of using global and local geographic information systems (GIS) to assess the potential of renewable energy sources in Ukraine. GIS analysis focused on key resource parameters can help identify territories for development of renewable energy sources and assess of their possible technical potential, as well as the possibility of effective integration of technologies for the use of renewable energy sources in the energy sector of Ukraine. In this paper the possibilities for using geographic information systems to assess the potential of renewable energy sources in Ukraine are analyzed. The possibility of using the Global Atlas of the International Renewable Energy Agency (IRENA) to support planning of technologies for the use of energy from biomass is analyzed. The data can point to large-scale programs and applications in relation to key parameters (quality resources, transmission distance, population density, terrain and site protection), helping identify additional areas for development of renewable energy sources and give an approximate assessment of technical potential. It is determined that the software products of IRENA are able to support national and regional planning of renewable energy technologies, help establish the viability of future renewable energy facilities and help project developers identify and analyze promising facilities for the implementation of technologies using renewable energy. The application of geographic information systems of Ukrainian web resources ("UA MAP") for assessing the potential of renewable energy sources and energy efficiency in Ukraine is been analyzed. The scientific novelty of the results lies in applying global and local GIS for comprehensive assessment of the potential and effectiveness of the use of regional non-traditional and renewable energy resources on the territory of Ukraine. This makes it possible to assess the possibilities of generating additional electric and thermal power for the needs of the regions of Ukraine using non-traditional and renewable energy sources. A comprehensive methodology for the use of GIS is proposed for assessing the potential of nontraditional and renewable energy sources at the regional level in Ukraine, taking into account energy, environmental and socio-economic factors affecting the placement of non-traditional and renewable energy facilities.
\end{abstract}

Keywords: geoinformation systems; renewable energy sources; renewable energy technologies; Ukraine 


\section{Introduction}

Important conditions for achieving energy security and energy independence are the reduction of energy consumption and energy intensity of production, by increasing the energy efficiency of technological processes using non-traditional and renewable energy sources of natural and man-made origin [1]. In developing countries, it is necessary to introduce large-scale modern technologies for the use of renewable and non-traditional energy sources, the pace of implementation of which is not yet fully consistent with the European level [2-4]. However, in the foreseeable future we should expect the development of renewable energy in Ukraine.

In addition to the typical use of geographic information systems (GIS) in the areas of business and commercial activities and the use of natural resources, GIS is widely used in the public sector, transport and utilities. It is important for the state to have an adequate analysis of data in order to effectively identify the most in-demand and scarce resources in a timely manner.

GIS are systems for collecting, accumulating, processing and graphical visualization of spatial (geographical) data about GIS objects. The main areas of GIS use are urban and regional planning, economic development (GIS applications provide detailed analysis of social, economic and topographic features), emergencies and disaster management (assessment and monitoring of the environment, modeling of ecological disasters and analysis of their consequences, environmental planning), law enforcement, oil and gas industry, roads and transport, geodesy and logistics of infrastructure.

The purpose of GIS is determined by the tasks associated with decision-making in the field of environmental design/planning, rational use of natural resources, the adoption of sanitary protection measures in emergencies, and so on.

It should be noted that at present, extensive data sets have been formed on the basis of global and regional GIS systems, which can become the basis for research in the fields of non-traditional and renewable energy. In parallel with the problems associated with the verification of data from GIS systems and the analysis of the adequacy of methods for obtaining these information data, a number of problems should be noted that arise due to the complexity of the visual display of the required data in a form convenient for analysis. An important task in processing information data on non-traditional and renewable energy sources is their accumulation in suitable databases, as well as mapping the potential of non-traditional and renewable energy sources for various regions of Ukraine.

In addition to substantiated scientific and methodological significance, studies of the regional potential of non-traditional and renewable energy sources in Ukraine are of great practical relevance. The analyzed databases and GIS should become an influential tool for analyzing the effectiveness of the practical use of non-traditional and renewable energy sources in the regions of Ukraine, as well as for supporting the adoption of sound technical and managerial decisions on the use of potential regional non-traditional and renewable energy sources.

The relevance of the present research is determined by the need to create methods for using the resource potential of GIS in the field of non-traditional and renewable energy sources, taking into account the possible prerequisites and restrictions for their development at the regional level. This approach makes it possible to carry out zoning of territories in order to select the most promising sites for projects for the development of non-traditional and renewable energy in the regions of Ukraine.

The use of GIS permits prompt and detailed analysis of the studied indicators, to assess the possibilities and potential of regional non-traditional and renewable energy sources. In particular, GIS permits assessment of the possibilities of generating additional electricity and heat for the needs of regions, and the potential effectiveness of alternative non-traditional energy. The use of GIS to substantiate and develop technologies for the use of renewable energy sources will solve a number of energy, environmental and economic problems of the regions of Ukraine. 


\section{Methodology}

In recent years, a number of scientific studies by various authors have been devoted to the application of geographic information systems to assess the potential of renewable energy sources [1-15]. As noted in a recent study [5], the relevance of this scientific topic is due to the fact that the use of renewable energy sources is assessed by the world community as one of the most promising ways to address growing energy supply and sustainable development needs [6].

In particular, the aim of these study [5] was to solve the current fundamental problem of environmentally safe use of a number of renewable energy sources in the Carpathian region of Ukraine, in line with the concept of sustainable development $[7,8]$. This was ensured by developing a scientific and methodological framework for strategic assessment of capacity and environmentally safe location of renewable energy sources, taking into account the sustainable development of the region $[9,10]$, determination of optimal technologies for the use of renewable energy such as solar, wind and small hydropower, and stabilization and improvement of the environment based on the principles of sustainable balanced development of the region [10-12].

In [5], the scientific substantiation of technically achievable, economically expedient and ecologically safe potentials of renewable energy sources through creation of a complex of maps of GIS-potentials of renewable energy sources in the region was presented. A number of technical and economic advantages, technological and environmental priorities for the studied renewable energy sources were identified [8-11].

The first study [5] presented research on the development of a methodology for environmentally safe use of renewable energy sources in the Carpathian region of Ukraine, taking into account the concept of sustainable development. The scientific novelty of the results was to justify the expansion of the resource potential of renewable energy sources in the Carpathian region of Ukraine with the creation of a set of maps in the geographic information system "Map Information". For each of the types of renewable energy sources (solar, wind, small hydropower) in the study, a number of technical advantages have been identified, and technological and ecologically safe priorities for their use have been assessed. The article provided a detailed calculation of wind, solar and hydropower regional potentials of renewable energy sources for the Carpathian region of Ukraine. The spatial limitations and possibilities of introduction of the considered renewable energy sources in the context of sustainable development of the region of Ukraine were scientifically substantiated. A number of scenarios for the use of renewable energy in Ukraine were proposed.

GIS are used for graphical construction of maps and for obtaining information on individual facilities and spatial data on oblasts, such as the location of natural gas reserves, the density of transport communications or the distribution of per capita income in the state. The areas indicated on maps in many cases reflect the required information much more clearly than dozens of pages of reports with tables. The effective application of GIS is based on mathematical modeling in order to ensure the effectiveness of monitoring the effectiveness of nature management.

In recent years, there has been a steady growth in global investment in renewable energy. In 2015, the share of renewable energy sources in the structure of new installed energy capacity in the world reached a record level at $54 \%$, which confirmed the long-term global trend in replacing traditional energy generation with renewable energy generation. In 2016, the share of renewable energy technologies in Europe accounted for $87 \%$ of all new installed capacity, which confirms the transformation of the European energy system in terms of replacing traditional renewable energy sources.

Our previous study [8] assessed the future trends in the reform of the energy sector of the world, the European Union and Ukraine up to 2050, using renewable energy sources and the concept of sustainable development. Our study [8] identified the benefits of using renewable energy sources and assessed the prospects for the use of innovative technologies based on renewable energy sources and the concept of sustainable development. A number of criteria for energy, economic and environmental efficiency of innovative technologies for 
the use of renewable energy sources were analyzed, to ensure comprehensive assessment of the effectiveness of energy- and resource-saving, environmentally-friendly and costeffective innovative technologies in the field of sustainable development. This approach allowed us to rationally determine the prospects for the use of energy and resource-saving, environmentally-friendly and cost-effective innovative technologies for the use of renewable energy sources in line with the concept of sustainable development, in order to increase energy and economic efficiency and the level of environmental safety of the energy sector of Ukraine [8].

In our study, an energy model for the use of renewable energy sources based on global and local GIS data was created and investigated. Thus, in our study, data from different GIS sources were used in terms of time and are explored to analyze the possibilities of using alternative renewable energy sources in the regions. Statistical data from global and regional statistical resources also were used.

The general approach to modeling in our studies is based on the system approach and system analysis, which involves the selection of the main object of the system, defining the purpose and evaluation criteria, defining methods to achieve the goal, determining the structure of the system and its elements and achieving efficiency, quality and optimality of the system.

GIS-based statistics can complement consumer needs data and compensate for data gaps through complementarity. Analysis and visualization of the results in the studies are carried out using software for the study of global and local GIS.

The aim of the present study is to assess the possibilities of using geographic information systems to assess the potential of renewable energy sources in Ukraine, with substantiation and expansion of opportunities to use global and local GIS to assess the potential of renewable energy sources in Ukraine based on GIS analysis. The study will analyze key resource parameters in order to define areas for the development of renewable energy sources and assess their possible technical potential, as well as considering the effective integration of technologies for the use of renewable energy sources in the energy sector of Ukraine.

In the study, the estimation of possibilities of application of geoinformation systems for estimation of potential of renewable energy sources in Ukraine is executed with use of methodological bases and scientific results from a number of previous studies [16-22], and also using databases and interactive resource maps on global renewable energy sources from the internet [23-27].

The scientific novelty of our results lies in the application of global and local GIS for solving the problems of a comprehensive assessment of the potential and effectiveness of the use of regional non-traditional and renewable energy resources on the territory of Ukraine. This makes it possible to assess the possibilities of generating additional electric and thermal power for the needs of the regions of Ukraine using non-traditional and renewable energy sources. For the first time, a comprehensive methodology for the use of GIS is proposed for assessing the potential of non-traditional and renewable energy sources at the regional level in Ukraine, taking into account energy, environmental and socio-economic factors affecting the placement of non-traditional and renewable energy facilities [26,27]. The proposed principles provide the basis for rational search for and selection of territories that are most promising for the placement of facilities for non-traditional and renewable energy in Ukraine.

\section{Results}

In 2018, Ukraine became a member of the International Renewable Energy Agency (IRENA). According to [28,29], the activities of IRENA ensure coordination and intensification of the work of countries' agencies for renewable energy development through analysis, formulation of recommendations, and transfer of knowledge and technologies.

The authors used the IRENA database to obtain the results shown in Figures 1-3. Figure 1 shows the dynamics of growth of the installed capacity of technologies for the 
use of renewable energy sources in Europe. Figure 2 shows the dynamics and structure of growth of the installed capacity of technologies based on renewable energy sources in Europe in 2016-2020.

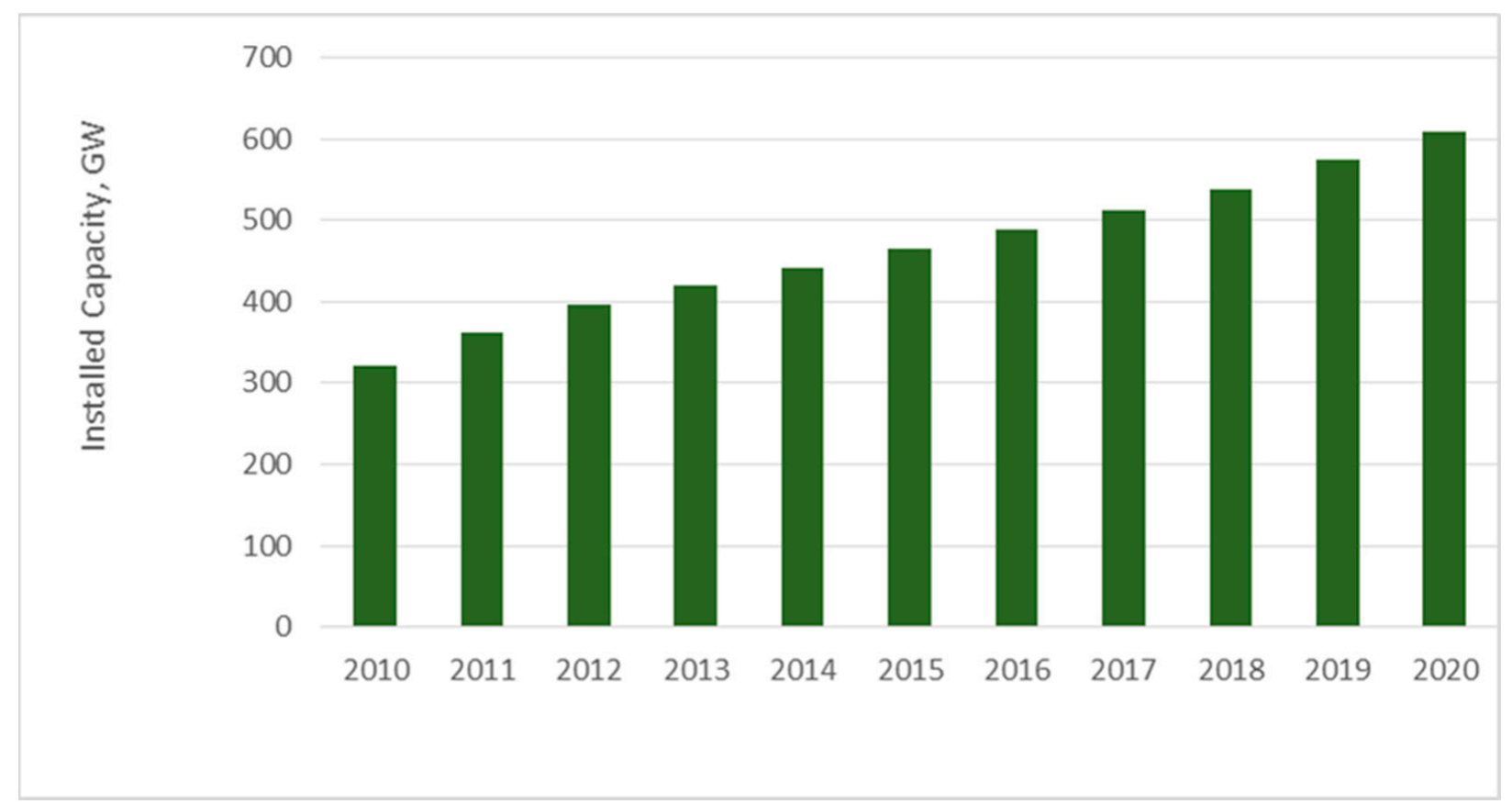

Figure 1. Dynamics of growth of the installed capacity of technologies for the use of renewable energy sources in Europe (IRENA).

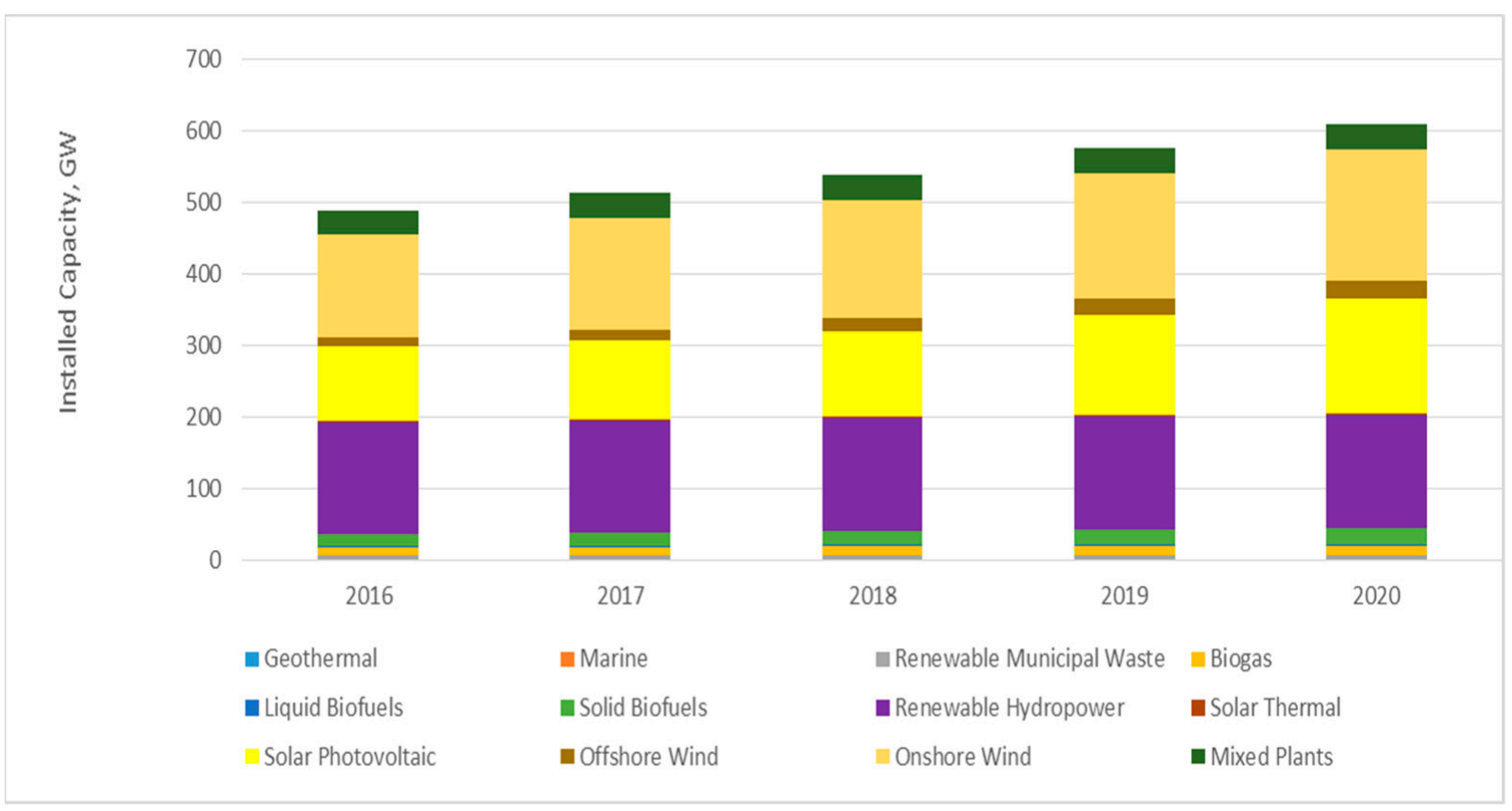

Figure 2. Dynamics and structure of growth of the installed capacity of technologies based on renewable energy sources in Europe in 2016-2020 (IRENA). 


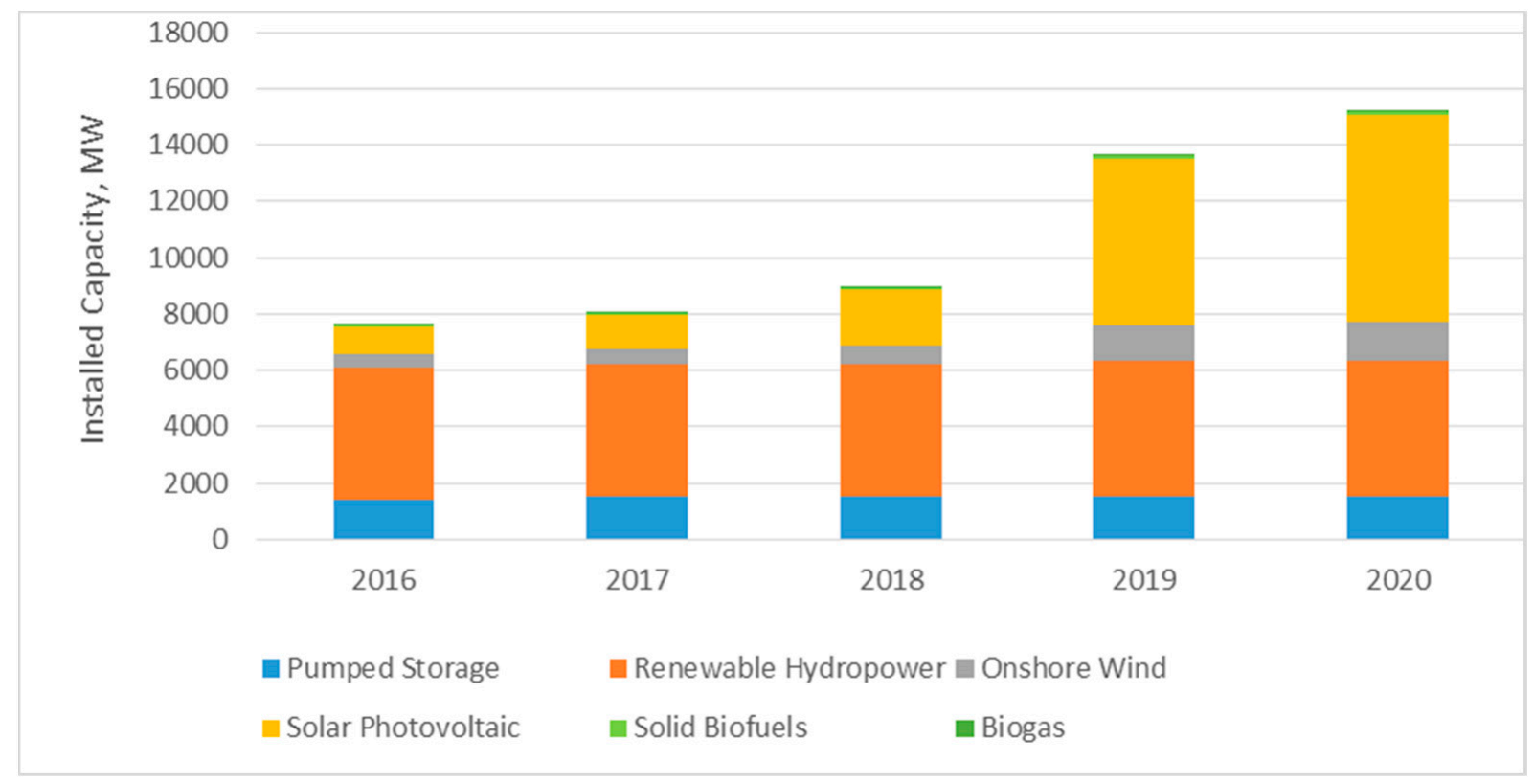

Figure 3. Dynamics and structure of growth of the installed capacity of technologies based on renewable energy sources in Ukraine in 2016-2020 (IRENA).

Figure 3 shows the dynamics and structure of growth of the installed capacity of technologies based on renewable energy sources in Ukraine in 2016-2020. IRENA member countries have the opportunity to use a number of software products of this organization, namely, statistics on the use of renewable energy (renewable capacity statistics) and the Global Atlas [30]. IRENA also offers a number of tools for the implementation of projects using renewable energy technologies: Project Navigator, Sustainable Energy Marketplace and IRENA/ADFD Project Facility.

The Global Atlas of the use of renewable energy sources is a web-based platform that provides users with access to renewable energy maps around the world.

More than 50 highly reputed international research institutes were involved in the creation of the Global Atlas, which provides more than 2000 maps with characteristics of renewable energy sources (solar, wind, bioenergy, geothermal and marine energy) on a single platform.

The Global Atlas zoning service provides GIS-based spatial analysis using the IRENA method for large-scale programs and applications, covering analysis of key parameters (quality of resources, distance to transmission networks, population density, terrain and protected areas) to determine suitable zones for the development of renewable energy sources and to give an approximate assessment of the technical potential.

IRENA software products are offered to support national and regional planning of renewable energy technologies in countries. The proposed technologies help to establish the viability of future projects for the use of renewable energy sources, and help project developers to characterize and analyze promising projects for the implementation of technologies using renewable energy.

Figures 4 and 5 show the selection of characteristics of renewable energy sources in the Global Atlas program from IRENA for any area with coordinates in Ukraine. This is based on reproduction of graphic material [30]. 


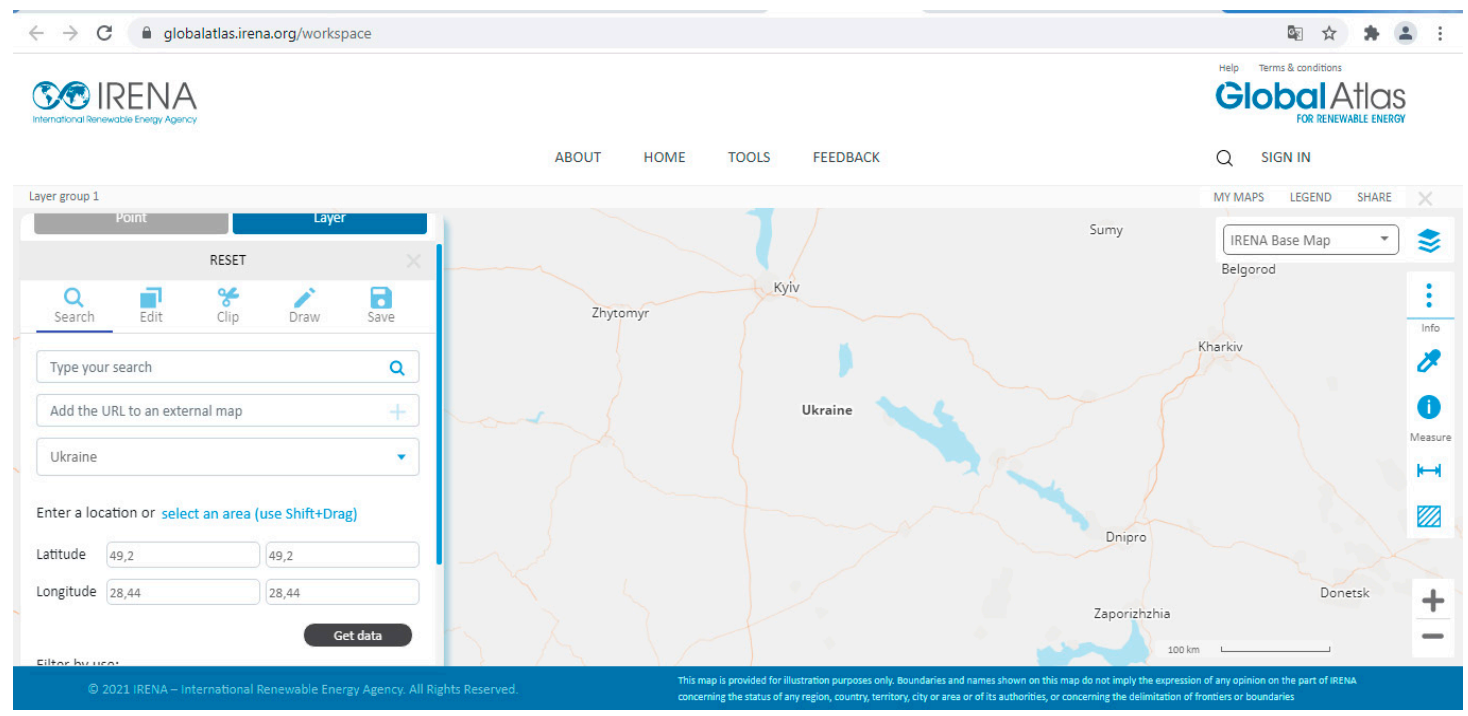

Figure 4. Selection of areas with coordinates in Ukraine to determine the characteristics of renewable energy sources in the Global Atlas program from IRENA (reproduction of graphic material from [30]).

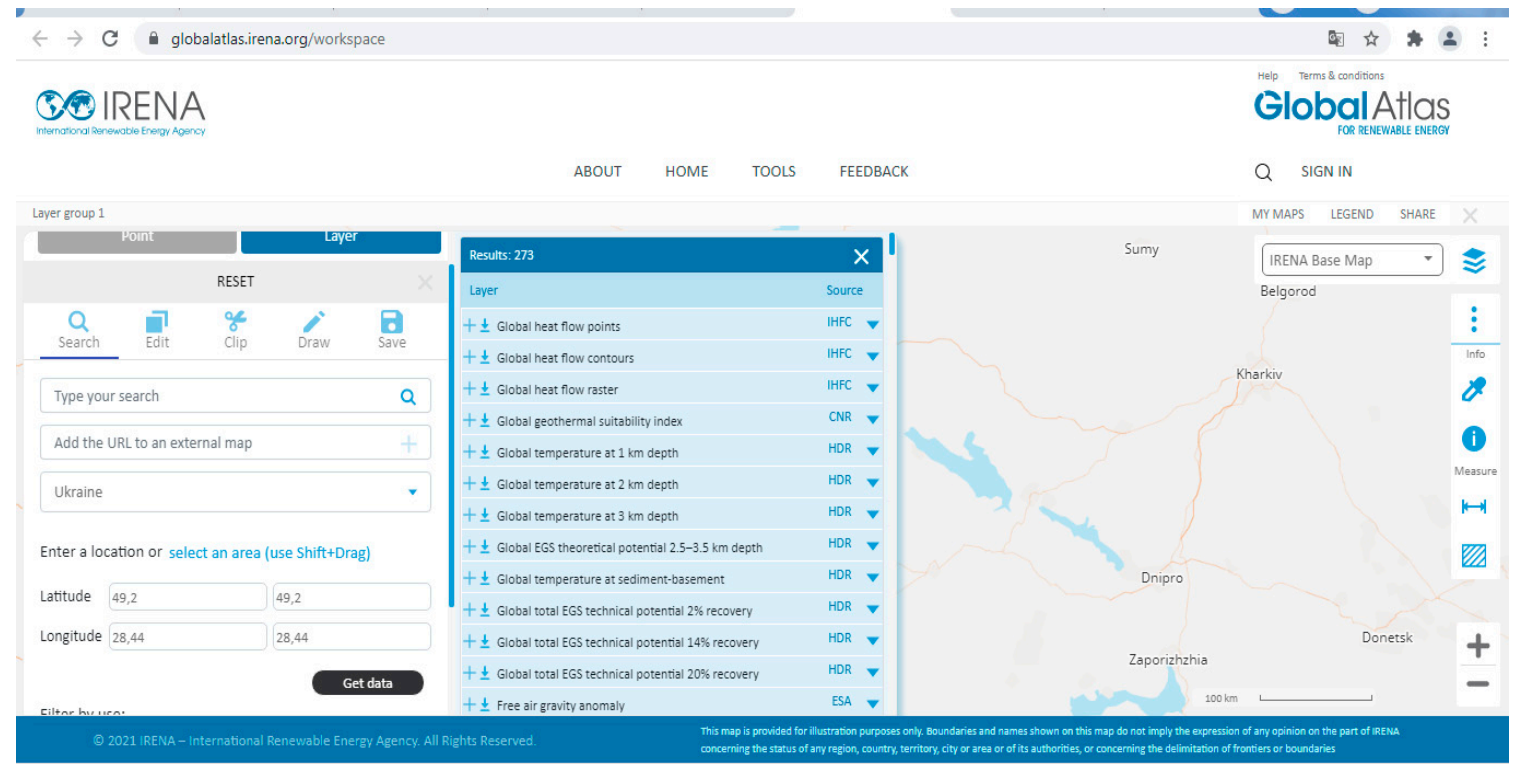

Figure 5. Selection of renewable energy characteristics in the Global Atlas program from IRENA for any area with coordinates in Ukraine (reproduction of graphic material from [30]).

\section{Discussion}

According to IRENA, based on the results of the analysis "REmap 2030" [31], Ukraine has significant potential for the development of solar and wind energy and the use of energy from biomass. According to the analytical review "REmap 2030", Ukraine can ensure a ten-fold increase in total end-use of renewable energy sources by 2030 (compared to 2009). According to forecasts, by 2030 the use of the potential of renewable energy sources in Ukraine will be distributed as follows: $73 \%$ of the potential will be provided in the heat industry, $20 \%$ in the electricity sector and $7 \%$ in the transport sector.

The use of Ukraine's additional potential in wind energy, biomass and solar photovoltaic will increase the share of energy produced from renewable sources in electricity production by $25 \%$ by 2030 . In addition to IRENA web resources, it is advisable to use geographic information systems from Ukrainian web resources to assess the potential of renewable energy sources in Ukraine. In particular, «UA MAP» [32-37] is a modern infor- 
mation web resource containing information on renewable energy and energy efficiency in Ukraine. The interactive investment resource map of Ukraine posted on the «UA MAP» website (Figure 6) reflects general information on renewable energy projects in Ukraine and provides data on the resource potential of the area. Figure 6 reproduces graphic material in [34].

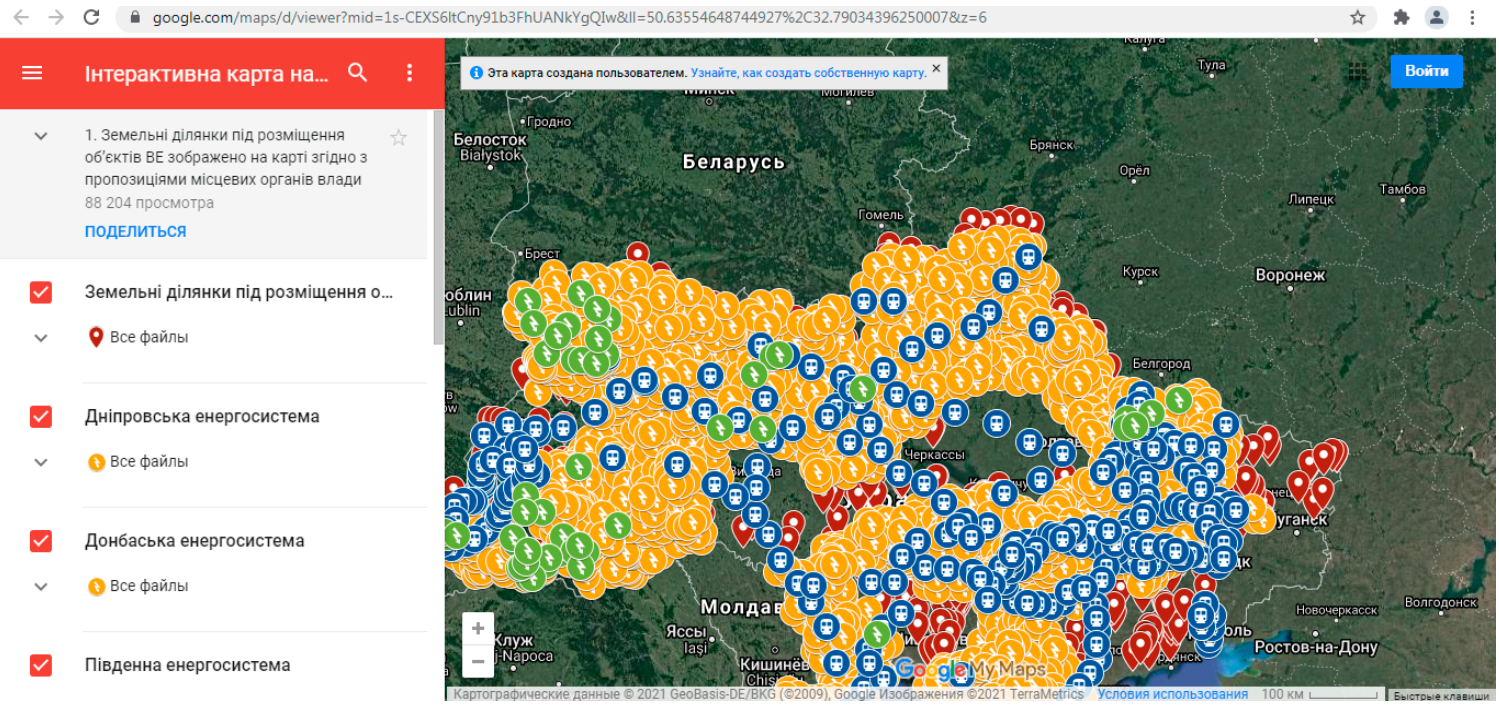

Figure 6. Interactive investment resource map of Ukraine "UA MAP" (reproduction of graphic material from [34]).

The «UA MAP» website contains an interactive online map of the energy sector of Ukraine (Figure 7), which shows the chains of energy transformations for the production of certain types of energy in Ukraine. Figure 7 is a reproduction of graphic material in [35].

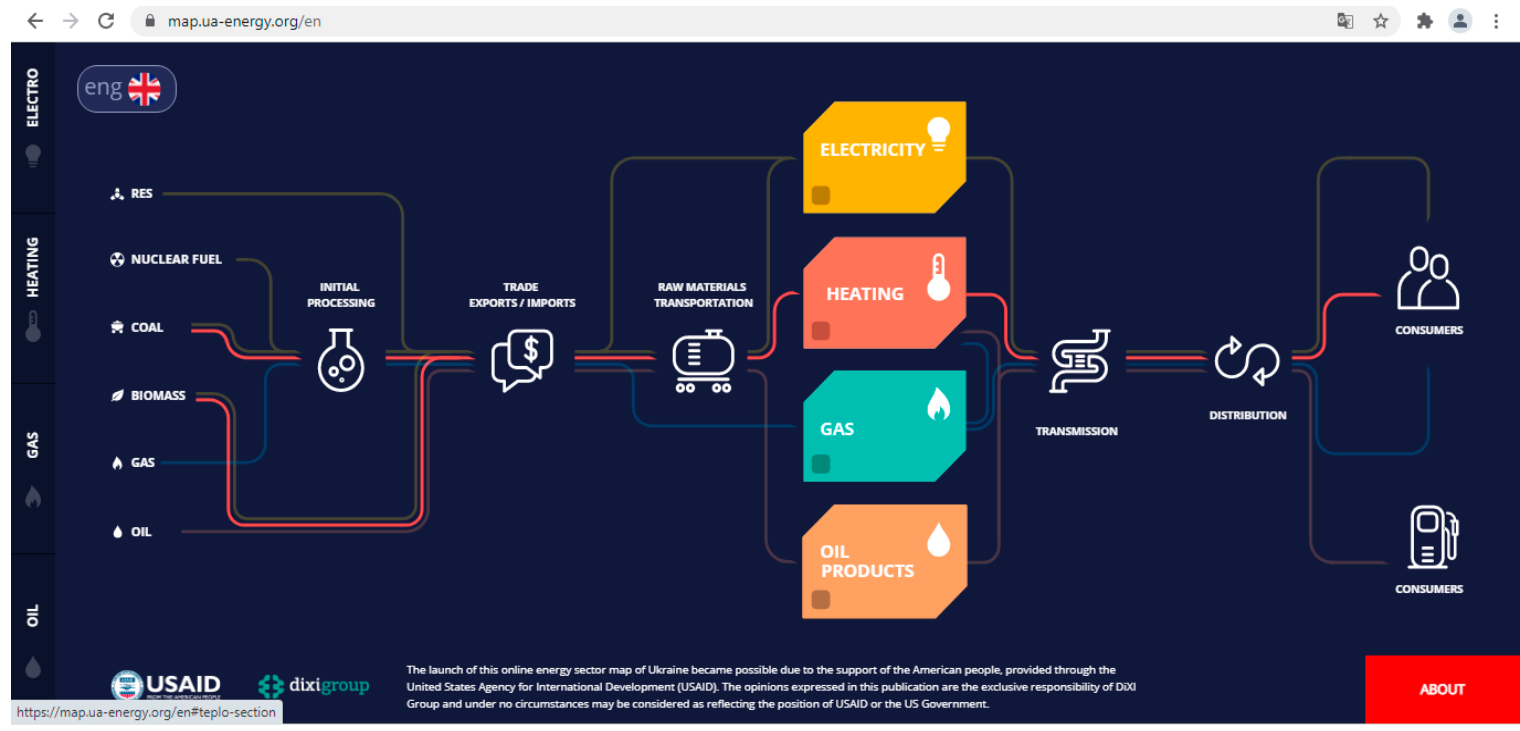

Figure 7. Interactive online map of the energy sector of Ukraine «UA MAP» (reproduction of graphic material from [35]).

Figure 8, for example, shows the chains of heat generation technologies in Ukraine based on traditional, non-traditional and renewable energy sources in the online map of the energy sector of Ukraine "UA MAP". Figure 8 is a reproduction of graphic material in [36]. In Figure 8, each tab provides outputs of statistical and balance data in Excel. 


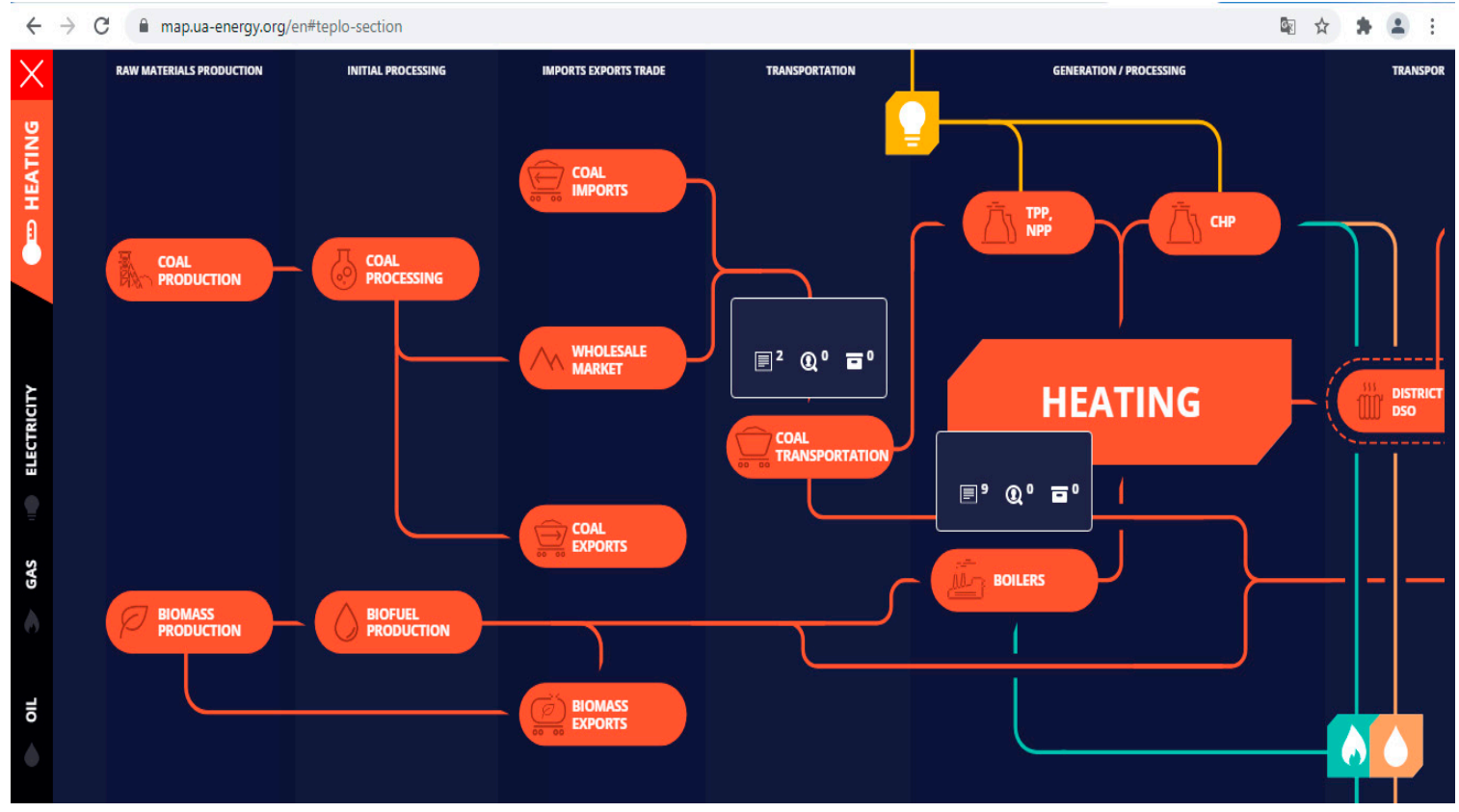

Figure 8. Chains of heat generation technologies in Ukraine based on traditional, non-traditional and renewable energy sources in the online map of the energy sector of Ukraine "UA MAP" (reproduction of graphic material from [36]).

The analyzed software products from the web resource "UA MAP" will permit assessment of the effective integration of certain technologies for the use of renewable energy sources in the energy sector of Ukraine.

The study shows the principles of using the generated vast data sets on the basis of the analyzed global and regional GIS systems, which are proposed to be used as a basis for research in the fields of non-traditional and renewable energy in Ukraine.

The study substantiates the scientific and methodological significance of GIS in studying the regional potential of non-traditional and renewable energy sources in Ukraine. This is of great practical use, since the analyzed databases and GIS should become an influential tool for analyzing the effectiveness of the practical use of non-traditional and renewable energy sources in the regions of Ukraine, as well as supporting the adoption of informed technical and managerial decisions on the use of potential regional non-traditional and renewable energy sources.

This paper study focuses on the need to create methods for using the resource potential of GIS in the field of non-traditional and renewable energy sources, taking into account the possible prerequisites and limitations for the development of non-traditional and renewable energy sources at the regional level. This approach makes it possible to carry out zoning of territories in order to select the most promising sites for projects for the development of non-traditional and renewable energy in the regions of Ukraine.

The study proposes the principles of using global and local GIS for solving the problems of a comprehensive assessment of the potential and efficiency of using regional non-traditional and renewable energy resources on the territory of Ukraine. This approach makes it possible to assess the possibilities of generating additional electrical and thermal power for the needs of the regions of Ukraine using non-traditional and renewable energy sources, to rationally assess the effectiveness of regional projects on the use of non-traditional and renewable energy sources in Ukraine.

The paper proposes a comprehensive methodology for using GIS to assess the potential of non-traditional and renewable energy sources at the regional level in Ukraine, taking into account energy, environmental and socio-economic factors affecting the placement of non-traditional and renewable energy facilities. The proposed principles provide a 
reasonable search and selection of territories that are most promising for the placement of facilities for non-traditional and renewable energy in Ukraine [38,39].

\section{Conclusions}

The scientific novelty of the results presented in this study is the substantiation and expansion of the possibilities of using global and local geographic information systems to assess the potential of renewable energy sources in Ukraine. GIS analysis aligned to key resource parameters permits identification of territories for development of renewable energy sources and assessment of their technical potential, as well as effective integration of technologies for the use of renewable energy sources in the energy sector of Ukraine.

The scientific novelty of the results obtained lies in the fact that the principles of applying global and local GIS make it possible to assess the possibilities of generating additional electric and thermal power for the needs of the regions of Ukraine using nontraditional and renewable energy sources, and to rationally assess the effectiveness of regional projects on the use of non-traditional and renewable energy sources in Ukraine. A comprehensive methodology for the use of GIS is proposed for assessing the potential of non-traditional and renewable energy sources at the regional level in Ukraine, taking into account energy, environmental and socio-economic factors affecting the placement of non-traditional and renewable energy facilities. The proposed principles provide for a rational search for and selection of territories that are most promising for the placement of facilities for non-traditional and renewable energy in Ukraine.

This paper analyzes the possibilities of using geographic information systems to assess the potential of renewable energy sources in Ukraine. The possibility of using the software products of the International Renewable Energy Agency, namely the Global Atlas, is analyzed.

This study confirms that the Global Atlas provides valuable spatial analysis based on GIS technologies using the IRENA method for large-scale programs and applications. This analysis of key parameters (resource quality, distance to transmission networks, population density, terrain and protected areas) permits determination of suitable areas for the development of renewable energy sources and gives an approximate assessment of the technical potential.

IRENA software products are offered to support national and regional planning of renewable energy technologies. The proposed technologies can help to establish the viability of future facilities for the use of renewable energy sources and help project developers to characterize and analyze promising facilities for the implementation of technologies for the use of renewable energy.

According to IRENA, based on the results of the analysis "REmap 2030", Ukraine has significant potential for the development of solar and wind energy, and the use of energy from biomass.

The application of geographic information systems from Ukrainian web resources to assess the potential of renewable energy sources in Ukraine is analyzed. The possibilities of the modern information web resource "UA MAP", which contains information on renewable energy and energy efficiency in Ukraine, are illustrated.

The study shows the principles of using the generated vast data sets on the basis of the analyzed global and regional GIS systems, which are proposed to be used as a basis for research in the fields of non-traditional and renewable energy in Ukraine.

The article substantiates the scientific and methodological significance of GIS in studying the regional potential of non-traditional and renewable energy sources in Ukraine, which is of great practical use. The analyzed databases and GIS should become an influential tool for analyzing the effectiveness of the practical use of non-traditional and renewable energy sources in the regions of Ukraine, as well as supporting the adoption of informed technical and managerial decisions on the use of the potential of regional non-traditional and renewable energy sources. 
The study focuses on the need to create methods for using the resource potential of GIS in the field of non-traditional and renewable energy sources, taking into account the possible prerequisites and limitations for the development of non-traditional and renewable energy sources at the regional level. This approach makes it possible to carry out zoning of territories in order to select the most promising sites for projects for the development of non-traditional and renewable energy in the regions of Ukraine.

The study proposes the principles of using global and local GIS for solving the problems of a comprehensive assessment of the potential and efficiency of using regional non-traditional and renewable energy resources on the territory of Ukraine. For example, this approach makes it possible to better assess the possibilities of generating additional electrical and thermal power for the needs of the regions of Ukraine using non-traditional and renewable energy sources, through regional projects.

The study proposes a comprehensive methodology for using GIS to assess the potential of non-traditional and renewable energy sources at the regional level in Ukraine, taking into account energy, environmental and socio-economic factors affecting the placement of non-traditional and renewable energy facilities. The proposed principles provide for a rational search for, and selection of, territories that are most promising for the placement of facilities for non-traditional and renewable energy in Ukraine.

The analyzed software products will permit assessment of the effective integration of certain technologies for the use of renewable energy sources in the energy sector of Ukraine.

\begin{abstract}
Author Contributions: Conceptualization, O.O. and V.K.; methodology, O.O.; software, O.O.; validation, O.O., P.O. and L.H.; formal analysis, D.M.; investigation, O.O., L.H. and O.P.; resources, V.K. and P.O.; data curation, O.O.; writing - original draft preparation, O.O. and V.K.; writing-review and editing, P.O. and D.M.; visualization, O.O.; supervision, L.H. and D.M.; project administration, P.O.; funding acquisition, L.H. All authors have read and agreed to the published version of the manuscript.
\end{abstract}

Funding: This research received no external funding.

Institutional Review Board Statement: Not applicable.

Informed Consent Statement: Not applicable.

Data Availability Statement: Not applicable.

Conflicts of Interest: The authors declare no conflict of interest.

\title{
References
}

1. Benalcazara, P.; Komorowska, A. Prospects of green hydrogen in Poland: A techno-economic analysis using a Monte Carlo approach. Int. J. Hydrogen Energy 2021. [CrossRef]

2. Zatserkovnyi, V.; Oberemok, N.; Puzyk, A. Geoinformation modeling in the problems of renewable energy. Bull. NTU "KhPI" Ser. New Solut. Mod. Technol. Kharkiv. NTU "KhPI" 2018, 9, 118-127. [CrossRef]

3. Olczak, P.; Komorowska, A. An adjustable mounting rack or an additional PV panel? Cost and environmental analysis of a photovoltaic installation on a household: A case study in Poland. Sustain. Energy Technol. Assess 2021, 47, 101496. [CrossRef]

4. Cader, J.; Olczak, P.; Koneczna, R. Regional dependencies of interest in the "My Electricity" photovoltaic subsidy program in Poland. Polityka Energetyczna Energy Policy J. 2021, 24, 97-116. [CrossRef]

5. Arkhypova, L.M.; Mandryk, O.M.; Moskalchuk, N.M.; Prykhodko, M.M.; Radlovska, K.O. Renewable energy resources in the system of sustainable development of Carpathian region of Ukraine. J. Phys. Conf. Ser. 2021, 1781, 012010. [CrossRef]

6. Sabishchenko, O.; Rębilas, R.; Sczygiol, N.; Urbański, M. Ukraine energy sector management using hybrid renewable energy systems. Energies 2020, 13, 1776. [CrossRef]

7. Ostapenko, O.; Savina, N.; Marnatova, L.; Zienina-Bilichenko, A.; Selezneva, O. Perspectives of application of innovative resource-saving technologies in the concepts of green logistics and sustainable development. Tour. Estud. Prat. (UERN) 2020, 2, $1-12$.

8. Ostapenko, O. Estimation of tendencies of transforming the energy sectors of World, European Union and Ukraine in the perspective to 2050 with using the renewable energy sources in the concept of Sustainable Development. In Book Social Capital: Vectors of Development of Behavioral Economics: Collective Monograph; ACCESS Press Publishing House: Veliko Tarnovo, Bulgaria, 2021; pp. 99-139. 
9. Arkhypova, L.; Fomenko, N.; Kinash, I.; Golovnia, O. Territorial Recreational Systems and Sustainable Development. Adv. Econ. Bus. Manag. Res. 2019, 99, 189-194.

10. Mandryk, O.; Moskalchuk, N.; Arkhypova, L.; Prykhodko, M.; Pobigun, O. Prospects of environmentally safe use of renewable energy sources in the sustainable tourism development of the Carpathian region of Ukraine. E3S Web Conf. 2020, $166,04005$. [CrossRef]

11. Mandryk, O.; Arkhypova, L.; Pukish, A.; Zelmanovych, A.; Yakovlyuk, K. Theoretical and methodological foundations of sustainable development of Geosystems. IOP Conf. Ser. Mater. Sci. Eng. 2017, 200, 012018. [CrossRef]

12. Matuszewska, D.; Kuta, M.; Olczak, P. Techno-Economic Assessment of Mobilized Thermal Energy Storage System Using Geothermal Source in Polish Conditions. Energies 2020, 13, 3404. [CrossRef]

13. Rutitis, D.; Volkova, T. Model for Development of Innovative ICT Products at High-Growth Potential Startups. Eurasian Stud. Bus. Econ. 2021, 19, 229-241.

14. Nitsenko, V.S.; Mardani, A.; Streimikis, J.; Shkrabak, I.; Klopov, I.; Novomlynets, O.; Podolska, O. Criteria for Evaluation of Efficiency of Energy Transformation Based on Renewable Energy Sources. Montenegrin J. Econ. 2018, 4, $253-263$.

15. Danyliuk, V.; Riepina, I.; Shafalyuk, O.; Kovylina, M.; Nitsenko, V. Functional and investment strategies of technical development of enterprises. Nauk. Visnyk Natsionalnoho Hirnychoho Universytetu 2020, 3, 115-121. [CrossRef]

16. Kinash, I.; Shtogryn, H.; Sakal, O.; Zapukhliak, I. The ecologization of housing and communal services of Ukraine in the context of sustainable development. J. East. Eur. Cent. Asian Res. 2019, 6, 113-130.

17. Kinash, I.; Arkhypova, L.; Polyanska, A.; Dzoba, O.; Andrusiv, U.; Iuras, I. Economic evaluation of tourism infrastructure development in Ukraine. IOP Conf. Ser. Mater. Sci. Eng. 2019, 477, 012020. [CrossRef]

18. Godfrey, B. Renewable Energy: Power for a Sustainable Future; Oxford University Press: Oxford, UK, 2012 ; p. 584.

19. Zelenko, Y.; Malovanyi, M.; Tarasova, L. Optimization of heat-and-power plants water purification. Chem. Chem. Technol. 2019, 13, 218-223. [CrossRef]

20. Mandryk, O.; Moskalchuk, N.; Arkhypova, L.; Pryhodko, M.; Pobigun, O. Research quantitative indicators of the potential of solar energy in the Carpathian region of Ukraine. IOP Conf. Ser. Mater. Sci. Eng. 2020, 749, 012033. [CrossRef]

21. Twidell, J.; Weir, T. Renewable Energy Resources, 3rd ed.; Routledge: London, UK, 2015.

22. Prykhodko, M.; Arkhypova, L.; Horal, L.; Kozhushko, S. Concept of ecosystem services and its implementation in Ukraine. J. Geol. Geogr. Geoecol. 2020, 29, 387-397. [CrossRef]

23. DataBank. WorldBank. Available online: https: / / databank.worldbank.org/reports.aspx?source=2\&country=UKR\# (accessed on 2 December 2021).

24. Esmap. Available online: https://www.esmap.org/ (accessed on 2 December 2021).

25. Eurostat. Available online: https:/ / ec.europa.eu/eurostat/data/database (accessed on 2 December 2021).

26. Eurostat. Energy Dependency. Available online: https:/ / ec.europa.eu/eurostat/statistics-explained/index.php?title=Energy_ statistics_-_an_overview\#Energy_dependency (accessed on 2 December 2021).

27. Tracking SDG7. Available online: URL:https://trackingsdg7.esmap.org/country/ukraine (accessed on 2 December 2021).

28. International Renewable Energy Agency (IRENA). Available online: https:/ / www.irena.org/ (accessed on 2 December 2021).

29. Statute of International Renewable Energy Agency (IRENA). Available online: https://irena.org/-/media/Files/IRENA/ Agency / About-IRENA/Statute/IRENA_FC_Statute_signed_in_Bonn_26_01_2009_incl_declaration_on_further_authentic_ versions.pdf?la=en\&hash=635C494208DD405EA8CD2BDB04414FECD40F55F1 (accessed on 2 December 2021).

30. Global Atlas of International Renewable Energy Agency (IRENA). Available online: https://www.irena.org/globalatlas (accessed on 2 December 2021).

31. Renewable Energy Roadmap of International Renewable Energy Agency (IRENA). Available online: https://saee.gov.ua/sites/ default/files/ENG\%20IRENA_REmap_Ukraine_paper_2015\%201304.pdf (accessed on 2 December 2021).

32. Ukrainian Cartographic Network UA MAP. Available online: https://uamap.org.ua/ (accessed on 2 December 2021).

33. Ukrainian Cartographic Network UA MAP. Resource Maps. Available online: https:/ / uamap.org.ua/resursnee-karti (accessed on 2 December 2021).

34. Ukrainian Cartographic Network UA MAP. Interactive Investment Resource Map. Available online: https://www.google.com/ maps / d/viewer?mid=1s-CEXS6ltCny91b3FhUANkYgQIw\&ll=50.63554648744927\%2C32.79034396250006\&z=6 (accessed on 2 December 2021).

35. Ukrainian Cartographic Network UA MAP. Interactive Online Map of the Energy Sector. Available online: https://map.uaenergy.org/en (accessed on 2 December 2021).

36. Ukrainian Cartographic Network UA MAP. Chains of Heat Generation in the Online Map of the Energy Sector. Available online: https: / / map.ua-energy.org/en\#teplo-section (accessed on 2 December 2021).

37. Ukrainian Cartographic Network UA MAP. Chains of Heat Generation from CHP and NPP in the Online Map of the Energy Sector. Available online: https://map.ua-energy.org/en/categories/teplo/tes-aes (accessed on 2 December 2021).

38. Sribna, Y.; Koval, V.; Olczak, P.; Bizonych, D.; Matuszewska, D.; Shtyrov, O. Forecasting solar generation in energy systems to accelerate the implementation of sustainable economic development. Polityka Energetyczna-Energy Policy J. 2021, 24, 5-28. [CrossRef]

39. Koval, V.; Sribna, Y.; Kaczmarzewski, S.; Shapovalova, A.; Stupnytskyi, V. Regulatory policy of renewable energy sources in the European national economies. Polityka Energetyczna-Energy Policy J. 2021, 24, 61-78. [CrossRef] 